\title{
Teologia, Ciência e Hermenêutica
}

Lindomar Rocha Mota

\section{Resumo}

O presente artigo investiga a relação entre ciência e teologia e sua mediação através da hermenêutica contemporânea a partir da necessidade de alargar o horizonte do discurso emergindo em elementos existenciais como principio de superação da experiência pura.

Palavras-chave: Teologia, Ciência, Hermenêutica, Experiência, Deus

\begin{abstract}
This article aims to investigate the relationship between science and theology as well as its mediation by contemporary hermeneutics. It focus on the need to broaden the horizon of the discourse that emerges as existential elements understood as a principle of overcoming pure experience as such.
\end{abstract}

Keywords: Theology, Science, Hermeneutics, Experience, God

\section{Introdução}

A possibilidade de Deus como objeto introduz no mundo um elemento distintivo na interpretação do homem e na visão que ele mesmo conserva de si. 
Desse modo, na ação constitutiva da ciência que pretende estudar Deus deve-se estar atento às suas diversas nomenclaturas e a sua linguagem, por vezes, estranha ao modo comum do discurso.

Nesse aparato complexo permanece latente o problema de individuar uma linguagem adequada para exprimir a teologia e suas derivações. Isso porque, na origem do fenômeno teológico se esconde uma realidade alternativa que alarga o horizonte da compreensão, pois seria absurdo considerar a teologia como fenômeno sem que existisse outra coisa que lhe sustentasse.

Uma boa definição epistemológica começa com a interrogação sobre a possibilidade de um discurso efetivo da teologia, uma reflexão sobre o nosso modo de linguagem e a sua capacidade de descrever a essa realidade.

Todavia, sabemos que nossa linguagem obedece a um parâmetro preciso: converte os objetos da representação em informações, uma convertio ad phantasma, isto é, conversão de imagens. Na teologia, entretanto, o que se identifica é a ausência deste phantasma, ou imagem possível para se fazer a representação.

Esse problema se direciona em diversos modos na formulação da teologia e evoca o difícil problema da hermenêutica.

Aqui se trata, portanto, de decidir, em sua primeira etapa, o relacionamento da teologia como principio de unidade para todas as coisas e como um problema para a razão humana, isto é, para nós. Outro ponto central complexo do pensamento teológico envolve a difícil tarefa de transformar o discurso existencial num princípio de unidade que se relaciona com os demais discursos.

\section{A teologia e a crise do "objeto"}

A questão do objeto é uma herança que a teologia herdou da ciência européia e da metafísica. Esse efeito se desdobra ao longo de sua história cujo influxo sobre o debate científico ainda se ressente.

Não é fácil para a teologia definir o seu objeto. Os teólogos começam esta procura por onde, em geral, as outras ciências já terminaram, Deus.

Numa proposição aceita pela teologia que a ciência contesta, diz-se o seguinte: Deus criou o mundo. Este raciocínio, entretanto, para a ciência é a crise da teologia. A ciência não é autorizada nem credencia a teologia a retirada do mundo de seu plano físico para elevá-lo ao metafísico.

Neste caso, a teologia, carece de fundamentos mais do que a ciência, pois a ciência pode começar a seu pensamento com uma pré-suposição da própria experiência, a teologia não. 
A ciência goza deste privilégio com relação à teologia. Seu objeto, graças às delimitações, anteriormente estabelecidas, é comum à própria razão, onde ela necessita apenas fazer a conversão da imagem à sua realidade comum. $\mathrm{O}$ que é impossível para a teologia, incapaz de unificar a idéia de Deus, e, logo, incapaz de tornar cientifico o seu discurso.

A questão intermitente entre a teologia e a ciência, portanto, ao contrário do que aparenta, não é um problema de linguagem ou de ideologia, é uma questão de fundamento.

O Fundamento segundo Leibniz é o princípio que sustenta todas as coisas, tanto fisicamente quanto em sua própria estrutura, como no caso do discurso. Tudo que existe, existe por um princípio de razão suficiente que fundamenta o objeto científico

A época moderna nega à teologia este princípio de razão suficiente, e, recentemente, a pós-modernidade a está negando também à ciência.

A teologia, então, e no Brasil não constitui uma exceção, é obrigada a buscar outro princípio de causalidade. Um princípio para preencher o itinerário na relação de causa e efeito.

Tendo Deus como objeto, a teologia pretende chegar a um fundamento fora do domínio da ciência. Um fundamento que não é retirado da experiência na maneira real do ser, mas um fundamento em sua própria maneira de ser. Uma tese que, já em seu ponto de partida, contrasta com a fórmula do fundamento, dada por Leibniz, e herdada pela ciência moderna.

A teologia vem acrescentando, contra a ciência, que nem tudo pode ser colocado dentro do grande princípio nihil est sine ratione. Existe algo que se coloca a partir de si mesmo, e que dá sentido a tudo.

Nesse caso, o fundamento, falando estritamente, evocaria um objeto que não se deixe envolver pela necessidade de outra coisa. Uma existência paradigmática que possibilita um discurso sobre a essência e sobre a existência. Uma espécie de sentido ausente no mundo.

A teologia é a "ciência" onde se pretende encontrar pela primeira vez a evocação deste ausente. Uma evocação que valeria para o fundamento e para a sustentação da existência de Deus como objeto. É a tentativa do discurso teológico de se organizar sem a presença de um objeto formal.

Esta unicidade teológica choca-se com a ciência porque eleva o pensamento para além da existência e evoca uma existência por trás da presença, uma quase presença. Ou seja, o fundamento que permite toda e qualquer comunicabilidade. A comunicabilidade é a pretensão da ciência, mas 
ela repousa sobre o fundamento, que em linha de princípio não é presença, mas é a quase presença que a teologia pretende possuir.

Como, porém, a razão científica já reduziu o horizonte de seu discurso descartando as questões transcendentais para demonstrar a exatidão de suas proposições o ponto de partida das duas parece ser o momento exato da ruptura. Enquanto a teologia pretende um encontro no terreno da existência a ciência prefere o campo da experiência, e, nesse choque, a teologia sofre sua grande crise.

A diferenciação que se faz, porém, não deve entrar para nós como a simplista divisão entre ciência e teologia, complicando assim a composição divisória entre as duas áreas do saber, e deslocando sua estrutura essencial para a angulação do observador e da sucessão temporal, como um segmento que pode produzir intrinsecamente o conceito de uma ciência.

Nasce uma divisão própria entre a ciência e teologia. Esta divisão tem que ser aceita até certo ponto. Não adianta chamar para o diálogo aquele que não quer dialogar. É preciso, encontrar o ponto justo e interessante para constituí-lo.

Essa possibilidade, se possível, acontece em torno de uma disputa clássica que envolve a continuidade e a permanência, antítese constante na história do pensamento.

A saga da tradição para o pensamento foi, desde sempre, estabelecida sobre concordância e discordância e sobre as condições da permanência e da imutabilidade, que depois se estrutura em diversas linhas discursivas, permanecendo presente, contudo, que, essa interação é o limite determinante da tentação de se pensar a essência das coisas ou os seus acidentes. De qualquer modo, encontramos de novo uma relação semelhante, quando pensamos a estrutura da teologia, reproduzindo em um terreno bastante fértil as dimensões desse confronto. Agora, pode-se retirar de algumas proposições, verdadeiramente kantianas, a conclusão de que, persiste no ato de conhecer uma forma do pensamento, uma lei que segue a ordem natural. $\mathrm{O}$ espírito aparece dotado de princípios que podem intervir validamente no terreno da ciência, formado, sobretudo com o caráter antitético (Gegensatz) que coloca em discussão a preeminência sobre qual ponto de vista determinará o mundo.

No fundo está em jogo uma visão de mundo e sua causalidade. Tanto a ciência quanto a teologia estão neste terreno complicado. Reduzindo o espaço entre as duas ao problema da causalidade surge uma pergunta ulterior, referente à condição de se executar uma passagem silogística do a-temporal ao temporal recavando nessa mesma passagem um proveito para o conhecimento. 
Kant, o primeiro a enfrentar a questão depois de Plotino, unificou a condição do conhecimento na representação e deixou no mundo transcendente os eventos a-temporais e com ele a teologia ${ }^{1}$.

A divisão entre o conhecimento como representação e a condição transcendente como suporte regulador instituída por Kant, entretanto, é para o próprio Kant, uma premissa que não pode ser abandonada, sem que para tanto se deva pagar um preço ainda mais alto do que a mesma convivência com a cisão ${ }^{2}$. A necessidade que se funda na operação silogística de passagem do a-temporal ao temporal não é, em linha de princípio, uma verdadeira necessidade, já que não falamos de modo definitivo de um verdadeiro incondicionado, que como tal impõe um ritmo a ser seguido pela ciência; é, em vez, a ciência quem dispõe metodologicamente o ritmo segundo o qual o objeto deve se apresentar diante do observador: temporal ou a-temporal como requisitado. É o valor que se dá na observação do evento a definir sua necessidade, o que significa que um evento de valor a-temporal pode, no decurso de um período, devir totalmente temporal.

O valor (nomos) funciona, então, como um princípio distintivo dado pela natureza metodológica da ciência.

A passagem do a-temporal ao temporal e vice e versa, tão cara a Kant, é representada pela inferência dos objetos nas faculdades do conhecimento. De algum modo, o intelecto é dependente das sensações para elaborar um conhecimento, de onde deriva o seu valor necessário para que eles sejam aquilo que devem representar ${ }^{3}$.

Essa passagem é uma espécie de profissão de fé kantiana, uma herança originária do pensamento de Leibniz sobre as vérités eternelles no intelecto divino e as vérités de fait na vontade divina. Um modo kantiano para reconduzir os dados da percepção sob as formas do intelecto e logo ordenado e compreendido como um sinal de conexão teleológica que supera, em larga escala, o saber teórico ${ }^{4}$.

O aspecto teleológico, portanto, citado comuma ênfase própria da Terceira Crítica kantiana, na verdade, expressa somente a possibilidade do intelecto de tomar para si as coordenadas da realidade, fundando a liberdade sobre a abstração da redução categorial da realidade noumenica. A tirar vantagem da

\footnotetext{
${ }^{1}$ KANT, I. Crítica da Razão pura. B659 ss. (Kant começa com uma crítica a toda teologia fundada em princípios especulativos da razão).

${ }^{2}$ Ibid

${ }^{3}$ Ibid

${ }^{4}$ KANT, I. Crítica da faculdade do juízo, §79ss
} 
abstração do conhecimento como fato, que não se dá à compreensão, não é mais a realização do desejo racional, mas sim o indivíduo, que se encontra livre diante de si mesmo e da tirania das suas categorias determinantes. Insinua-se desse modo a necessidade de salvar qualquer coisa como realidade em si, mas o trabalho de restauração se desloca automaticamente para a apreciação de uma realidade exclusiva, que está essencialmente a fundamento de tudo, mas que carece de salvação, isto é, a personalidade (Persönlichkeit).

A liberdade (Freiheit) se expressa como um sentimento (Gefühl), apenas entrado na parte teórica da reflexão filosófica, de onde aprendemos que a salvaguarda dos objetos inatingiveis da ciência, se constitui somente sob a condição que aumente, agora uma vez em nós, a possibilidade determinativa com relação ao mundo circunstante. Se em Kant a liberdade é apenas uma realidade analítica, neste confronto entre teologia e ciência é um objeto do conhecimento, que por hora vem exclusivamente através do sentimento negativo da autonomia, mas que tenderá a se universalizar com a proposta de um mundo fundado sobre os princípios da existência ${ }^{5}$.

Portanto, a questão da crise do objeto da teologia se corrige ao interno da própria crise na seguinte elaboração: se a ciência é o que conta, enquanto capaz de determinar o seu objeto proveitosamente, a teologia não, por que então a teologia não é desprezada no horizonte humano?

\section{A virada hermenêutica}

Falar de hermenêutica exige uma pré-compreensão do lugar de sua fertilização. A modernidade endureceu o discurso contra a debilidade da razão, e impôs um limite preciso para a relação entre ciência e teologia.

A modernidade é o lugar da medida justa, do enquadramento perfeito a partir de princípios demonstráveis. Mesmo o antigo discurso sobre o uno, preponderantemente filosófico, mas que a teologia soube se aproveitar muito bem, decaiu diante da modernidade.

A ciência moderna deixou de se preocupar não com o uno, e passou se concentrar nos únicos, que evoluíram de cultura imperfeita a objeto da ciência $^{6}$. Onde se negou qualquer possibilidade de teologia, que ainda ressente na difícil tarefa de transformar o seu discurso em discurso cientifico, com pouca chance de conseguir.

\footnotetext{
${ }^{5}$ Ibid

${ }^{6}$ ROCHA MOTA, L. Identidade da técnica e o controle do mundo, p. 130-136.
} 
A pós-modernidade, neste contexto, é a negação da modernidade. Ela contesta a modernidade enquanto indica a necessitar de ontologia e a carência de sentido vida. Neste ponto Kant foi negado ao dizer que as pessoas não precisam de um sentido para agir.

A época pós-moderna fez naufragar os barcos de um more geometrico cartesiano que poderia explicar tudo. A pós-modernidade é ontológica, explica também pelos sentimentos e neste sentido é a própria ambigüidade da modernidade se revelando.

A hermenêutica só emerge mediante a desilusão com a força do Logos. O abandono do uno pela modernidade gera a procura propriamente hermenêutica da unidade na diversidade - nos vários únicos. A este ponto, o discurso sobre Deus volta como um dos tantos únicos possíveis da pós-modernidade. Entretanto, a teologia continua pretendendo que Deus seja o principio de unidade de todas as coisas.

Em sua autodefinição a teologia seria essa unidade das unidades, a razão de Deus sobre ele mesmo. Por isso, a ciência moderna abandonou o discurso do uno. Os únicos levam à multiplicidade e o que interessa é conhecer as unidades, a especialização; logo, a modernidade não poderia aceitar Deus como principio de unidade, pois impediria a explosão nas multiplicidades que tanto lhe interessa. A razão pós-moderna, com coerência, foi chamada de débil, razão humana que busca recuperar um princípio de unidade e transportá-lo para o domínio analítico.

A hermenêutica repropõe a questão da separação entre ciência e teologia em outro patamar. Não se trata de encontrar outro objeto para teologia, mas sim, ampliar a questão da teologia às demais ciências do seguinte modo: até que ponto é constatável a exatidão da matemática, da física, da química?

Essa capacidade de reconstituição funda a essência contemporânea da hermenêutica. Neste contexto, poderíamos arriscar que caímos na pós-modernidade com uma nova necessidade de Deus, porque as coisas precisam de um sentido, mediante o qual a geometria cede lugar ao método ontologizante.

O ponto de partida da hermenêutica é a carência humana que precisa de um ponto de unidade. Podemos falar de Deus partindo de nós e da carência que há em nós. Para Kant, o homem equilibra esta carência com a esperança, um postulado da razão que garante a unidade 7 . Esta sugestão kantiana é contestada por Nietzsche, que ver o perigo de um retorno a

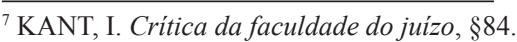


teologia e a metafísica. Este ponto é uma ruptura entre os dois filósofos. O primeiro acha que o homem, em sua carência latente necessita de certo conforto, inclusive para agir eticamente, enquanto que o segundo contesta os dois pontos desta hermenêutica, evitando a necessidade da esperança e da moral.

\subsection{A hermenêutica}

Para entrar no domínio deste debate, a teologia não pode iniciar o seu discurso com a revelação. A revelação não é passiva de hermenêutica, mas uma percepção imediata de uma finalidade sem contornos. A abertura deixada pela pós-modernidade, embora tenha reintroduzida a teologia no debate do saber humano, não permite que o discurso se inicie por uma afirmação.

As regras da hermenêutica são postas diante da teologia e exige uma abertura incondicional para o diálogo. A primeira destas aberturas que o teólogo deve executar é a percepção que antes da teologia pensar Deus a filosofia já o pensava.

\subsection{Da unidade filosófica à teológica}

A filosofia encontra-se as voltas com o problema da unidade desde o tempo de Platão. O Uno que está sobre a diferença possibilita o discurso no meio da diversidade da aparência. Conhecer a "verdade" é uma operação que exige um aproximar-se gradual daquilo que em verdade é, a essência. Do mesmo modo, Aristóteles se preocupava com o pensamento de Deus a partir de sua percepção do mundo. O mundo, neste caso, é carente de justificativa, onde Deus não é o problema, mas sim a estrutura inadequada do mundo que carece ser corrigida pela teologia.

A hermenêutica teológica de Aristóteles, parte da relação de causa e efeito para chegar a uma idéia sem movimento. Nela, Aristóteles se ver obrigado a passar da filosofia á teologia. No quadro das ramificações possíveis das ciências que poderiam responder coerentemente ao problema do princípio do movimento estão a física e a matemática, entretanto, nenhuma delas parece encontrar satisfatoriamente uma resposta, restando, portanto, esta tarefa a outra ciência, uma filosofia primeira, uma teologia ${ }^{8}$.

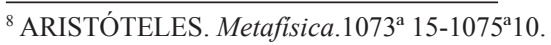


Aristóteles se propõe a falar desta ciência que estuda o ser enquanto ser, cuja tarefa é encontrar o ser supremo. Mas este não é discurso fácil, nem para iniciante, a teologia emerge de uma hermenêutica negativa que retira a relação de causa e efeito a partir do infinito.

O ponto de partida de Aristóteles é a justificativa do ser, mas para isso, surge a necessidade implícita de se falar de um ser que é causa de todos os outros seres, atingido através da vida teórica, que nem mesmo é a nossa atividade natural, embora seja a mais desejada. O objeto da teologia é uma existência racional que foge de qualquer definição material, o que inviabiliza um debate partindo do princípio da matemática ou da física.

De Aristóteles a Kant a idéia de Deus permaneceu no cerne da razão humana. Deus é um princípio de unidade das ações humanas. Com Kant este princípio se infiltra no interior da razão. O pensamento postula Deus para chegar à coerência em uma perspectiva de fé, é bem verdade, mas sempre uma coerência9.

Quando se trata da virada hermenêutica teológica surge o complexante de se dever passar do princípio de unidade do Deus filosófico para o Deus existente do teólogo.

As provas clássicas da existência de Deus não colaboram neste debate. A modernidade eliminou este tipo de argumento, ele não garante nada de racional, por isso, a racionalidade se sustenta sobre si mesma.

\subsection{A hermenêutica teológica e as demais ciências}

Karl Rahner, célebre teólogo alemão, interessado neste debate, sustenta a favor da teologia, que toda ciência, mesmo a empírica, tem como início um ponto de vista, que não precisa ser necessariamente evidente ou experimentado, pode provisório que só se torna ciência somente se superar algumas provas ${ }^{10}$.

Existe uma lei provisória, e esta lei é um pressuposto de que exista um principio que lhe dê unidade. Sem esta pressuposição inicial qualquer ciência naufragaria. O principio do método cientifico pressupõe a unidade como base - entretanto, ela não pode ser demonstrada - a unidade é pressuposta como uma necessidade do método teórico para não ocorrer na pluralidade.

Rahner sustenta que existe uma relação entre todas as ciências, mas descobrir esta relação não é tarefa de nenhuma delas, mas sim da metafísica. Este espírito condiz com a virada hermenêutica da pós-modernidade,

${ }^{9}$ KANT, I. Crítica da faculdade do juiz, §88ss.

${ }^{10}$ RAHNER, K. Filosofia e teologia in $O$ dogma repensado, p. 16 ss. 
onde, a rigor, a questão do início não um verdadeiro problema no interior das ciências ${ }^{11}$.

O problema aqui é o da relação como ponto de partida, reconhecer outro ser que esteja como originalidade para os demais. Mas é preciso começar do fenômeno, algo que seja aceito pela ciência e pela teologia: o homem. Pois, começar com Deus certamente atrapalharia o diálogo.

A existência é o fundamento da teologia e não a sagrada escritura. Sobre ela há poucas chances de se conseguir uma hermenêutica frutuosa, tendo em vista o seu caráter ligado a revelação.

A existência é o princípio auto-suficiência de toda a realidade, uma razão suficiente que passa pela historia como principio de investigação cientifica. Se faltar a existência o seu lugar será preenchido pelo mito. Logo, a existência é um principio que pede para si a capacidade de dar fundamento ao objeto.

Eu busco da verdade, a pós-modernidade abandona a concepção do objeto puro, a ciência passa a se basear nas diversas concepções, unidas exclusivamente através da existência, onde, a própria concepção do objeto muda e a essência cai fora do objeto para se concentrar no sujeito. Esse possível desaparecimento do objeto inaugura a hermenêutica. Não existe razão definitiva para dizer que o objeto é assim - o objeto fica variável na ordem do discurso.

Todo ponto de vista torna-se provisório. A provisoriedade aparece como uma condição geral da pesquisa cientifica. Que lei provisória é esta? É a pressuposição de um princípio que lhe dê a realidade. Sem essa pré-condição nenhuma ciência é possível.

O discurso científico, entretanto, mostra sua fragmentação em mais sentidos que a teologia. Falta até mesmo fundamento comum do falar. O discurso sobre a unidade não é um discurso comum das ciências, cuja necessidade aparece velada na pressuposição de sustentação de suas verdades.

Este não é um discurso abandonado pelas ciências apenas por capricho, este abandono ocorre porque o princípio emerge como algo indemonstrável, como já afirmou Aristóteles no Organon: se for demonstrado deixa de ser um princípio.

A ciência recebe este duro golpe de viver na multiplicidade pressupondo a unidade necessária do discurso. Na teologia, a este ponto o uno emerge por toda parte: o corpo, a alma, Deus, mas as outras ciências não podem identificar o seu 
princípio de unidade como a teologia faz, por isso, o perigo da fragmentação é constante. A pressuposição do uno é condição preliminar da ciência, uma questão que tradicionalmente foi concedida a teologia, ou ciência do ser.

Toda ciência é fundada sob o domínio do uno. Uma condição decisiva para dar unidade a objetos diferentes. Enquanto que a modernidade eliminou este tema do seu horizonte, a pós-modernidade reconhece ser este um princípio da razão humana, e, logo, concernente a existência. A teologia, aqui, segue esta investigação como uma filosofia da religião, que investe não tanto sobre o objeto, mas sim sobre a possibilidade de relação do homem com Deus. A esse ponto, a filosofia da religião, adaptada à mentalidade hermenêutica, não quer provar a existência de Deus ou do homem, mas tão somente a relação que existe entre ambos. E aqui ela reassume o seu papel de ser uma ontologia universal, tão cara à tradição católica.

O discurso teológico, então, não pode se basear sobre sentimento, mas fazer desta relação uma ontologia fundamental. Deus é um problema para nós, e não para Ele mesmo. O princípio é uma condição necessária para existência das outras coisas. Deste modo, a teologia assume, juntamente com a metafísica, o papel de ser uma ciência dos princípios.

\section{A teologia e a hermenêutica}

Como ponto de partida, a teologia não retira o seu objeto das sagradas escrituras. Ela não serve, aqui, para fomentar a estrutura científica da teologia. Sendo assim, o discurso deve passar por mais de uma perspectiva para entrar no horizonte da hermenêutica.

A teologia deve obrigar-se tanto do sagrado quanto do profano e aceitar a consistência do mundo como mundo. O profano também tem a sua autonomia, e o discurso deve começar muito mais com o ele do que com Deus.

Num horizonte mais largo, o profano é sacro para o cristão. Algo não pode retirar a sua existência de si mesmo, e é ela que está em questão, não simplesmente por ser sagrado, mas porque carece de um fundamento. Sustentar a existência a partir de sua sacralidade é o risco constante do panteísmo que ronda a teologia. Mas, aceitar que o profano também é uma via que revela o divino é a teologia interpretando a si mesma.

A divisão do mundo em profano e sagrado pode ser perigosa para a hermenêutica. Mesmo mediante esta divisão terminológica o profano deve ser respeitado em sua autonomia, até mesmo porque sacralizar o mundo não 
diz nada a respeito de Deus. Sacro e profano, assim como teologia e ciências, devem se revelar num relacionamento aberto.

Em parte, o cristianismo foi o grande responsável por esta dessacralização do cosmos, uma condição necessária para o desenvolvimento das ciências. As ciências modernas surgiram depois do desencantamento do mundo operado pela patrística. Jesus mesmo dessacralizou o sagrado por várias formas. E, nessa dessacralização o catolicismo sempre sacralizou virtudes iguais para pessoas diferentes, no catolicismo nem as pessoas são sacras, mas tão somente a virtude das pessoas.

Esse processo de dessacralização é condição necessária para que a teologia seja compreendida em um diálogo aberto com as demais ciências. A delimitação que existe entre ambas pode até ser a mediada hermenêutica do próprio diálogo, entretanto, se assumir uma forma absoluta terminará com a própria morte da teologia.

\subsection{Questões hermenêuticas para o pensamento de Deus}

Em 1979, logo após ter se tornar papa, em vários discursos João Paulo II começou a falar de nova evangelização, referindo-se tanto a Europa quanto às Américas.

O papa começou a falar de "novos" métodos e "novas" formas, indicando o processo de re-evangelização, visando particularmente os países de origem e cultura cristãs, que vivem sobre o efeito de descristianização.

O papa fala de "novos" métodos. Estes devem ser novos de modo bastante particular indicando que a diversidade da situação presente é radicalmente separada de qualquer outro tempo experimentado na história

É um tempo peculiar de interpretação duvidosa entre o dizer e o fazer. Traz suas raízes da laicização do Estado e se espalha agora, para uma suspeita mais generalizada, atingindo um terreno muito mais amplo.

A caracterização, surgida no próprio terreno da Igreja, aponta uma tentativa mais abrangente. A necessidade de uma nova evangelização indica que alguma coisa ficou velha, ultrapassada; não responde mais às necessidades metódicas de sua proposta original.

Chamar atenção para os novos métodos é denunciar certo estado de coisas e se autodenunciar, indicando que algo ficou velho e já não são compreendidas. Sendo assim, faz-se necessário encontrar outra saída para a crise do evangelho e da teologia. 
Alguns fatores estão à base desta crise. Como tais se espalham em diversos campos, entretanto, uma linha bastante exeqüível trata da compreensão que o homem moderno tem de sua fé, e como esta é atingida atualmente por denúncias originais em relação aos problemas anteriores.

\subsection{O campo hermenêutico do discurso teológico}

A teologia moderna vive, atualmente, no domínio da secularização. A secularização é um fenômeno que tem sua origem no século XIII com fim do sacro-império romano, e a situação do conflito político entre Bonifácio VIII e Felipe, o belo que afirmou o caráter laico nos diversos setores da atividade humana. Um acontecimento que determinou a instauração da secularização foi a guerra das religiões nos séculos XVI e XVII, que se alastrou por toda a Europa. A partir daí buscou-se outro caminho para a sobrevivência social, descobrindo assim a necessidade de superar as referências religiosas aprendendo a descartar a idéia de Deus e, sobretudo, aquelas de Igreja, buscando um novo ponto de encontro no terreno comum da razão e da natureza.

A reviravolta cultural é acentuada em campo filosófico pela substituição do pensamento platônico que valorizava os aspectos mais transcendentais da vida, pela filosofia de Aristóteles voltada intrinsecamente para os problemas do mundo. Em 1324, Marcílio de Pádua escreve o seu defensor pacis colocando a base do Estado moderno: liberdade do controle eclesiástico. A este evento sucederam um alastramento nos diversos campos do saber incluindo a ciência, a filosofia e a teologia. Max Webber por fim proclamou o domínio absoluto da razão sobre qualquer outra tentativa de união proclamando o desencantamento do mundo. Em certo aspecto a desilusão histórica substitui a visão cultural que sustentava a necessidade do sacro, mudando definitivamente a percepção da verdade. Este fenômeno responde pelo nome de secularização.

A secularização é uma procura quase que desesperada da autonomia.

Com ela o mundo perdeu os caracteres de ser uma realidade regulada pelas leis divinas e se tornou essencialmente histórico.

Com a mudança no conceito de mundo também o homem experimentou a queda e a dúvida sobre sua própria interpretação substituindo a única consciência que tinha de si o homem conquistou uma mentalidade multifacetária juntamente com um espaço maior de liberdade e de dependência mais responsável, mais crítico, mais só. 
A secularização cancelou a imagem unitária do mundo. A visão dominante, aquela cristã, que dominou a época pré-moderna perde amplamente o seu terreno. $\mathrm{O}$ indivíduo livre de qualquer pré-interpretação nega-se a inserir-se num caminho pré-ordenado, que dava aparentemente um princípio de unidade. A vida do secularismo é o pluralismo, enquanto oferece uma multidão de possibilidades, revelando por sua vez a desorientação, a efemeridade, o relativismo e o indiferentismo como causas ligadas a sua própria identidade.

A secularização esfacelou o monopólio da verdade, ela aparece se encontrar no próprio caminho que o indivíduo traça para si. A teologia confrontou-se e continua se confrontando com essa realidade, por vezes, propondo o seu oposto na forma de um integralismo que busca sair da multiformidade secular. A partir do séc. XX o secularismo entrou no próprio terreno da religião, especificada numa corrente teológica que se intitulou teologia da secularização. Um dos maiores representantes dessa teologia foi o teólogo protestante Dietrich Bonhöeffer ${ }^{12}$. A experiência e a situação experimentada nos cárceres nazistas e a iminência da morte produziram no teólogo uma reinterpretação da teologia. O pensamento de Bonhöeffer coloca em dúvida alguns princípios tradicionais da teologia. Um conflito aberto entre um Deus forte e onipotente, apto a resolver qualquer situação, e um Deus débil que não pode e não deve resolver as grandes questões da vida, porque morreu numa cruz. A situação levantada nas reflexões de Bonhöeffer coloca a teologia ante um profundo questionamento de suas estruturas e lança uma névoa fina, mas extensa, sobre o próprio conceito de Deus. Se Deus é definido pela concepção de onipotência, que tudo pode, e não intervém em situações extremas, a fim de salvar o inocente coloca em crise a sua própria onipotência ou a sua bondade; se de outra parte Deus não é onipotente perde o poder de intervir no mundo e nas disputas humanas abrindo duas margens para a interpretação do conceito de Deus: ou ele de fato não é onipotente e estamos abandonados às nossas próprias decisões ou, pior ainda Deus é onipotente, não intervém no mundo simplesmente porque não se importa $\operatorname{conosco}{ }^{13}$.

Em ambos os casos estamos diante de uma escolha decisiva. Optar por uma e por outra não é uma tarefa fácil, mas vem se desenrolando naquele processo iluminista que o filósofo alemão Kant chamou de idade da razão ${ }^{14}$.

\footnotetext{
${ }^{12}$ Cf. BONHÖEFFER, D. Resistência e Submissão, cartas e anotações escritas na prisão. S. Leopoldo, Sinodal, 2003.

${ }^{13}$ É a formulação clássica contra as provas da existência de Deus.

${ }^{14} \mathrm{Cf}$. KANT, I. O conflito das faculdades, p. 37-41
} 
A incursão de Bonhöeffer no mundo teológico exonera a culpabilidade de Deus ante a necessidade de que o homem se faça autônomo. A autonomia e o secularismo aparecem como um processo intrínseco a própria teologia, a saber, a verdadeira religião de um Deus que se distingue imensamente dos humanos e das atividades humanas. Somente interpretando amplamente a teologia de Bonhöeffer pode-se pensar que a autonomia humana e não Deus é o fim último da religião.

Frente às catástrofes humanas revela-se uma face de Deus há muito conhecida, mas pouco confessada, isto é, que Deus é Deus por que nos deixa sem Deus. De agora em diante não resta outro caminho à humanidade a não ser aquele de percorrer solitariamente o seu destino. A secularização implica deste modo na vivência definitiva da autonomia.

Tornou-se necessário nos últimos tempos rever a definição da imagem tradicional de Deus.

Com uma sensibilidade apurada alguns teólogos acreditam que só é possível falar de Deus dentro da história ou partindo da história. É dali que se emerge um nome novo, uma história nova. Esta novidade traz em si a possibilidade de se falar do divino na cidade secular, de um divino colhido na esperança da história sem negar, entretanto, a validade autêntica do mundo que se apresenta em sua forma secular.

$\mathrm{Na}$ história a única coisa que o homem faz é esperar. Um esperar silencioso sempre aberto a ouvir as próprias revelações nascidas dos próprios acontecimentos do mundo.

Numa análise mais apurada a secularização reduz a religião a uma antropologia.

Ultimamente está se reavaliando o processo de secularização a partir de uma crítica interna que vai de encontro a sua ideologização e algumas ilusões nascidas dentro dela que não são menos desconcertantes do que as próprias críticas endereçadas à teologia.

Naquilo que diz respeito à Igreja, não se pode negar certa docilidade com o tema do secularismo e a sua evolução ao longo dos documentos eclesiásticos.

De uma condenação em bloco do secularismo no Sílabo de Pio IX passase a uma visão mais dialogal nas linhas da Gaudium et Spes 55 e 75 do Concílio Vaticano II, onde se afirma tudo o que compõe a ordem temporal, isto é, os bens da vida e da família, a cultura, a economia, as artes e as profissões, as instituições da comunidade política, as relações internacionais, etc, as suas evoluções e os seus progressos possuem um valor próprio. Esta docilidade faz 
passar da conflituosa relação entre a teologia e as ciências a uma hermenêutica própria do mundo que teologia faz.

\subsection{O mal como hermenêutica da contestação}

O mysterium malum sempre esteve presente na história da humanidade. Falar de Deus em linha de princípio implica em considerar seriamente o problema de malum. O sofrimento do mundo não parece, atualmente, ser maior do que aqueles experimentados no passado longínquo.

Entretanto, o homem moderno é muito mais crítico em relação ao mal do que qualquer homem de outra época. De fato, São Tomás de Aquino começa com uma suspeita "parece que Deus de fato não existe: se de dois contrários um é infinito, o outro cairá completamente destruído. Ora, no nome de Deus se afirma um bem infinito. Logo, se Deus existisse, não deveria existir o mal. Vice versa no mundo existe o mal. Logo, Deus não existe"15.

A experiência trágica no século passado se concretizou em ícones e símbolos da pura maldade onde Deus parecia poder muito pouco.

Auschwitz, Hiroshima, Ruanda, se revelaram como aspectos relativamente problemáticos para a experiência de fé e para a questão de Deus. Como bem atestou o teólogo alemão Moltmann comentando Adorno, depois de Auschwitz não se pode mais fazer poesia. O que conduz a pergunta se ainda é possível continuar falar de Deus? Ainda é possível fazer teologia?

Uma das esperanças profundas da religião foi sempre aquela da vitória de Deus sobre o mal até a sua destruição total. O acréscimo do mal parece impor a necessidade de que Deus se revele ao mundo. O homem pré-moderno sempre viveu sob essa expectativa.

$\mathrm{Na}$ modernidade o mal se desmascarou através dos eficientes meios de comunicação onde, quase tudo, tornou-se transparente, ficamos sabedores de tudo e acumulou-se uma quantidade de informação tal que em apenas um dia supera todas as notícias que o homem medieval recebia durante toda sua vida.

Esse novo contexto acentuou o poder do mal e proclamou a impotência de Deus em resolver tamanhas catástrofes. Uma suspeita generalizada se dirige contra a eficácia da religião e a existência de Deus. Se em eventos traumáticos e decisivos para a história humana como Auschwitz, Hiroshima e Ruanda Deus não se revelou o que será preciso ainda para que Ele se revele?

${ }^{15}$ Aquino, Tomás de. Suma teológica, I, q.1,a.2 
Esta idéia se dilata por toda a literatura moderna e é um traço decisivo na hermenêutica dos suspeitosos, a exemplo de Nietzsche, que exclamam em alta voz: se Deus ainda não se revelou é porque não se revelará mais.

As dores do mundo é uma torre de sustentação para a negação de Deus. Juntamente com essa suspeita acrescenta-se um aspecto profundamente sentimental como exprime Arkel: se eu fosse Deus haveria mais compaixão dos sofrimentos dos homens. A idéia de humanismo que supera a própria bondade de Deus é patente na modernidade.

O supremo modelo de acusador contra Deus é Ivan Karamazov na alma escura do mundo, não menos maléfico de Dostoievsky quando exclama: nego absolutamente a harmonia suprema. Ela não vale uma lágrima nem mesmo de uma daquelas crianças quase mortas que se batiam no peito com o pequeno punho e rezava ao bom Deus na sua casa fedorenta, derramando as suas lágrimas sem serem vingadas. Ela deverá ser resgatada, do contrário não se poderá nem mesmo falar de harmonia... demasiadamente se exagerou o valor daquela harmonia isto é o céu, o ingresso custa muito caro para os nossos bolsos. E, por isso, apresso-me em devolver o meu bilhete de entrada.

Praticamente não se pode ser mais radical contra Deus do que a crítica de Ivan. A experiência do mal o conduz a um aberto ateísmo onde Deus se torna um grande responsável num debate entre os limites da existência e não no conflito com a ciência.

\section{Conclusão}

Volta a tona, deste modo, o problema do homem, discutido pela pretensão de uma narração teológica, bem entendida, como o problema da cultura, frente a qual se coloca explicitamente a irredutibilidade do mundo.

A teologia encontra seu objeto válido nesta passagem, cujo objeto primeiro é a cultura e o segundo o bem supremo; isto se nota com clareza quando além da decidida posição histórica da teologia, examinamos o extrato constitutivo que a liberdade possui nesta idéia. O fim que o homem dá à sua história, em si mesmo é um aperfeiçoamento da cultura em geral e sua elevação até o grau mais alto possível. Esse fim é de duas espécies; num primeiro caso é a mera capacidade de pensar-se como fim último da natureza a permitir esta idéia (objeto da ciência); no segundo caso, é a idéia de Deus, como necessidade humana de unidade existencial.

Não obstante a inteiração feita na história do desenvolvimento cultural fica clara a distinção entre o último fim da natureza e o fim último da criação, pois 
"apesar da semelhança verbal entre o último fim de natureza e o fim último da criação, eles são conceitualmente distintos", prospectada muito mais sobre a simbiose lingüística do que sobre as vias de fato. Do momento que certos fins não podem ser inerentes a qualquer coisa de conhecido nas coisas naturais, situando-se em um plano que já ultrapassou tais coisas, e que a mesma natureza deve se submeter; tudo isso como legalidade dada à própria forma natural. Esta percepção finalista, aos moldes da ciência antiga, conduz o discurso para o contexto teológico como expansão do confronto entre experiência e existência.

A teologia é obrigada, como qualquer ciência, a adequar seu objeto à razão humana e a necessidade da cultura. Sem essa possibilidade hermenêutica, ela terminaria como fadada ao fracasso do tempo e da própria necessidade imposta pela cultura.

\section{Referências Bibliográficas}

Aquino, Tomás de. Suma teológica. 2. ed. Porto Alegre: Escola Superior de Teologia São Lourenço de Brindes, 1980.

Aristóteles. Metafísica. São Paulo: ed Loyola, 2002.

BONHÖEFFER, D. Resistência e Submissão, cartas e anotações escritas na prisão.

S.Leopoldo, Sinodal, 2003.

Kant, I., Crítica da faculdade do juízo. Rio de Janeiro: Forense Universitari, 2005

Kant, I., Crítica da razão pura. Lisboa; Colauste Golbenkian, 1994.

Kant, I., O Conflito das faculdades. Lisboa, ed 70, 1993.

Rahner, K. Filosofia e teologia in O dogma repensado. São Paulo: Paulinas. 1970

Roсна Mota, L., Identidade da técnica e controle do mundo in Oliveira, P. e Souza José C., Consciência planetária e religião. São Paulo: Paulinas, 2009.

Lindomar Rocha Mota

Mestre em Teologia e Filosofia Doutor em Filosofia Moderna/PUG Professor na PUC Minas e no Seminário de Diamantina

Artigo Recebido em 22/05/2011 Artigo Aprovado em 23/06/2011 